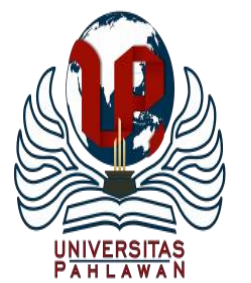

Jurnal Abdidas Volume 1 Nomor 5 Tahun 2020 Halaman 325 - 329

JURNAL ABDIDAS

Community Development Service on Educational and Health Sciences http://abdidas.org/index.php/abdidas

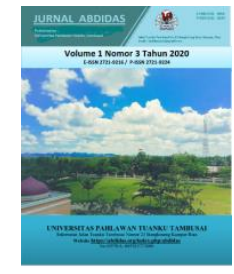

\title{
Penyuluhan ASI Eksklusif Untuk Mencegah Stunting Pada Ibu Hamil Di STIKES Citra Delima Bangka Belitung
}

Riza Savita ${ }^{1}$, Fitra Amelia ${ }^{2}$

STIKES Citra Delima Bangka Belitung, Bangka Belitung, Indonesia ${ }^{1}{ }^{2}$

E-mail : rizasavita55@gmail.com ${ }^{1}$ fitraamelia.fa@gmail.com²

\begin{abstract}
Abstrak
Stunting merupakan gangguan pertumbuhan linier dan apabila terjadi pada masa golden-period perkembangan otak (0-3 tahun), maka berakibat pada perkembangan otak yang tidak baik. Adanya hasil dari penelitian dengan judul hubungan pekerjaan ibu, jenis kelamin, dan pemberian ASI Eklusif terhadap kejadian stunting pada balita 6-59 bulan di Bangka Selatan dengan hasil ada hubungan antara pekerjaan ibu $p$-value $(0,000)$ dan ASI Eklusif $p$-value $(0,004)$ dengan kejadian stunting pada balita 6-59 bulan di Kabupaten Bangka Selatan serta tidak ada hubungan antara jenis kelamin dengan kejadian stunting pada balita 6-59 bulan di Kabupaten Bangka Selatan. Dari data tersebut kami tertarik melakukan pengabdian masyarakat dengan cara memberikan penyuluhan ASI Eksklusif untuk mencegah stunting. Metode yang kami lakukan dengan menggunakan leaflet dan lembar balik agar ibu hamil bisa mendapatkan informasi secara maksimal. Pelaksanaan dalam kegiatan pengabdian kepada masyarakat ini dilaksanakan Desember 2019 di STIKES Citra Delima Bangka Belitung. Kegiatan ini diikuti oleh 12 orang ibu hamil.
\end{abstract}

Kata kunci: stunting, ASI Eksklusif, ibu hamil

Abstract

Stunting is a linear growth disorder and if it occurs during the golden period of brain development (0-3 years), it results in poor brain development. The results of the research with the title Relationship between Mother's Work, Sex, and Giving ASI Eksklusif Against Stunting Incidence in Toddlers 6-59 Months in South Bangka, with the result that there is a relationship between maternal occupation p-value $(0,000)$ and ASI Eksklusif p-value (0.004) with the incidence of stunting in children aged 6-59 months in South Bangka Regency and there was no relationship between sex and the incidence of stunting in children aged 6-59 months in South Bangka Regency. From this data, we are interested in providing community service by providing ASI Eksklusif education to prevent stunting. The method we do is using leaflets and flipcharts so that pregnant women can get maximum information. Implementation in this community service activity was carried out on December 2019 at STIKES Citra Delima Bangka Belitung. This activity was attended by 12 pregnant women.

Keywords: stunting, ASI Eksclusif, pregnant woman

Copyright (c) 2020 Riza Savita, Fitra Amelia

$\triangle$ Corresponding author

Address : STIKES Citra Delima Bangka Belitung

ISSN 2721-9224 (Media Cetak)

Email : rizasavita55@gmail.com

ISSN 2721 - 9216 (Media Online)

Phone : :082279857667

DOI : https://doi.org/10.31004/abdidas.v1i5.64 
DOI : https://doi.org/10.31004/abdidas.v1i5.64

\section{PENDAHULUAN}

Hasil Riset Kesehatan Dasar tahun 2013, menyatakan bahwa prevalensi kejadian balita stunting di Indonesia mengalami fluktuatif pada tahun 2007, tahun 2010 dan tahun 2013. Data tersebut menyatakan bahwa persentase kejadian balita stunting pada tahun 2007 sebesar (36,8\%), pada tahun 2010 terjadi penurunan kasus balita stunting sebesar $(35,6 \%)$ dan pada tahun 2013 mengalami peningkatan sebesar $(37,2 \%)$ kasus balita stunting (Badan Penelitian dan Pengembangan Kesehatan Departemen, 2013).

Kasus balita stunting di Provinsi Kepulauan Bangka Belitung dari tahun 2015 hingga tahun 2017 terjadi peningkatan prevalensi stunting pada balita usia 0-59 bulan menurut indeks tinggi badan menurut umur (TB/U). Pada tahun 2017 prevalensi stunting tertinggi terdapat di Kabupaten Bangka Selatan sebesar (30,0\%), Kabupaten Belitung Timur sebesar (29,3\%), Kabupaten Bangka sebesar (27,7\%), Kabupaten Belitung sebesar (27,7\%), Kota Pangkalpinang sebesar (26,7\%), Kabupaten Bangka Tengah sebesar $(25,6 \%)$ dan terendah Kabupaten Bangka Barat sebesar (25,0\%). Persentase tersebut dengan pembagian kategori sangat pendek dan pendek (Dinas Kesehatan Provinsi Kepulauan Bangka Belitung, 2017).

Stunting merupakan gangguan pertumbuhan linier dan apabila terjadi pada masa golden-period perkembangan otak (0-3 tahun), maka berakibat pada perkembangan otak yang tidak baik. Hal tersebut di masa yang akan datang dapat berakibat pada penurunan kemampuan intelektual dan produktivitas, peningkatan risiko penyakit degeneratif dan kelahiran bayi dengan berat lahir rendah atau premature (Waroh, 2019).

Menurut UNICEF pertumbuhan pada balita dipengaruhi oleh faktor langsung diantaranya adalah asupan energi, asupan protein, BBLR, dan keadaan kesehatan seperti penyakit infeksi dan faktor tidak langsung meliputi pemberian ASI Eksklusif, jenis kelamin balita, tinggi badan ibu, tingkat pendidikan ibu dan status ekonomi. Upaya masyarakat dalam membantu menurunkan prevalensi stunting dapat dilakukan dengan cara melalu kunjungan anak ke posyandu tepat waktu. Sehingga pertumbuhan anak dapat terpantau dengan baik dan dapat mencegah stunting (UNICEF, 2013).

Air Susu Ibu (ASI) merupakan makanan terbaik bagi bayi. ASI eksklusif mampu menurunkan angka kesakitan dan kematian anak. Menurut Peraturan Pemerintah Republik Indonesia Nomor 33 tahun 2012 tentang Pemberian ASI Eksklusif, ASI Eksklusif adalah ASI yang diberikan kepada bayi sejak dilahirkan selama enam bulan tanpa menambahkan dan atau mengganti dengan makanan atau minuman lain (Salamah and Prasetya, 2019).

ASI Eksklusif adalah bayi hanya diberi ASI saja selama enam bulan tanpa tambahan cairan lain seperti susu formula, jeruk, madu, air teh, dan air putih, serta tanpa tambahan makanan padat seperti pisang, bubur susu, biskuit, bubur nasi dan nasi tim kecuali vitamin, mineral dan obat (Ludha and Maulida, 2012).

Berdasarkan penelitian oleh (Savita and Amelia, 2020) membuktikan adanya hubungan antara ASI Eklusif dengan kejadian stunting $(p=$ 
0,004) dimana balita yang tidak mendapatkan ASI eklusif memiliki kecenderungan 3 kali akan mengalami stunting dibanding balita yang mendapatkan ASI Eklusif (OR=2,634).

\section{METODE}

a. Tujuan Persiapan

Tahap persiapan dari kegiatan adalah pembuatan pre-planing, persiapan leaflat, lembar balik dan alat-alat lainnya disiapkan oleh mahasiswa STIKES Citra Delima. Pembuatan leaflat lembar balik dimulai pada hari rabu tanggal 18 tahun 2019, pada tanggal 21 Desember 2019 dilakukan persiapan penyuluhan cegah stunting dengan ASI Eksklusif.

b. Tahapan Pelaksanaan

Acara ini dengan pemberitahuan kepada ibu hamil melalui kader di keluarahan wilayah kacang pedang dan dilanjutkan penyuluhan tentang cegah stunting dengan ASI Eksklusif

\section{HASIL DAN PEMBAHASAN}

Sebelum pelaksanaan kegiatan pengabdian kepada masyarakat, dilakukan beberapa persiapan. Pertama, tim menganalisis hasil penelitian yang dilakukan pada tahun 2019. Selanjutnya, menentukan alternatif pemecahan masalah yaitu melaksanakan penyuluhan tantang ASI Eksklusif untuk pencegahan stunting. Setelah itu, melakukan melakukan koordinasi dengan pihak STIKES Citra Delima Bangka Belitung dan wilayah sekitar Kelurahan Kacang Pedang sesuai dengan sasaran. Tim mempersiapkan surat pemberitahuan pelaksanaan penyuluhan kesehatan. Kemudian, mengidentifikasi dan mempersiapkan kebutuhan pelaksanaan kegiatan meliputi: spanduk, SAP, leafleat, absensi, konsumsi.

Kegiatan pengabdian kepada masyarakat dilaksanakan pada tanggal 21 Desember 2019 di STIKES Citra Delima Bangka Belitung. Tim terdiri dari 2 orang Dosen DIII Kebidanan dan 2 orang mahasiswa DIII Kebidanan.

Rangkaian acara pada kegiatan penyuluhan adalah yang pertama pembukaan oleh pembawa acara (mahasiswa) kemudian sambutan dari ketua prodi DIII Kebidanan dan kepala Unit Penelitian dan Pengabdian Masyarakat. Selanjutnya, penyampaian materi oleh tim pengabdian masyarakat.

Peserta pengabdian yang terdiri dari 12 orang ibu hamil sangat antusias mengikuti kegiatan ini. Mereka sangat aktif selama proses penyuluhan berlangsung. Pada ibu hamil yang pertama kali hamil mereka sangat senang mendapatkan materi tentang ASI Eksklusif dikarenakan merupakan ilmu baru yang mereka dapatkan. Dalam sesi tanya jawab, ada 5 orang yang bertanya tentang ASI Eksklusif.

Hasil observasi dari penyuluhan ini mereka mengetahui hal-hal tentang ASI eksklusif. Penyampaian materi yang dilakukan sudah menyeluruh, terkait anggapan yang tidak benar tentang ASI mereka jadi mengetahuinya. Adapun harapan ibu hamil ketika sudah melahirkan mererka akan memberikan ASI kepada bayinya selama 6 bulan tanpa makanan pendamping apapun dan akan melanjutkan pemberian ASI selama 2 tahun dengan didampingi makanan yang lainnya. 
Melalui penyuluhan ini diharapkan ibu hamil nanti dapat memberikan ASI Eksklusif kepada bayinya, dan selalu mengikuti program pemerintah (posyandu) untuk memeriksakan bayinya terutama $\mathrm{BB}$ dan TB bayi/balita agar dapat selalu termonitoring oleh tenaga kesehatan dalam pencegahan stunting.

Kegiatan pengabdian ini diakhiri dengan foto bersama ( dosen dan ibu hamil).

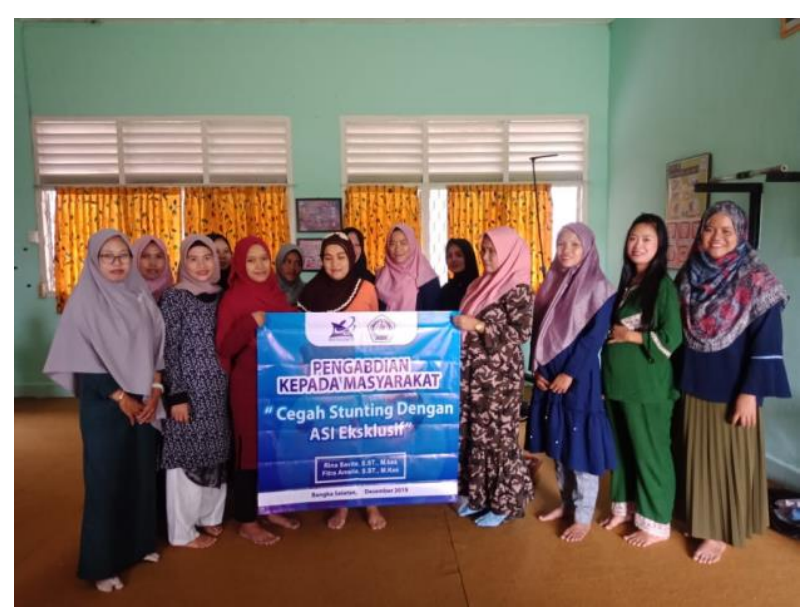

Gambar 1. Pelaksanaan Penyuluhan Tentang Cegah Stunting Dengan Asi Eksklusif

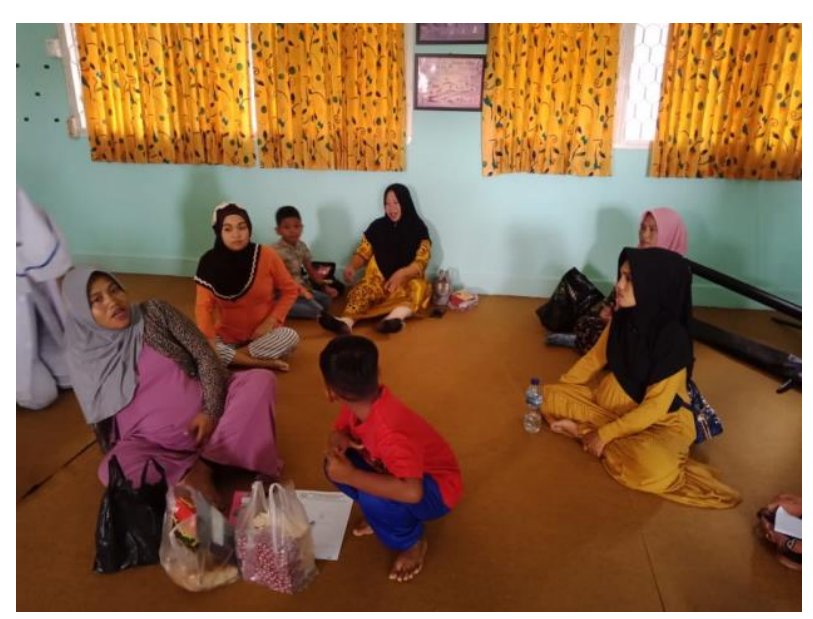

Gambar 2. Diskusi dan Tanya Jawab Tentang Materi penyuluhan
Berdasarkan kegiatan pengabdian dapat diberi kesimpulan perhatian dan respon dari peserta penyuluhan secara umum baik. Ibu hamil dapat memahami serta menabah pengetahuan lebih luas menganai ASI Eksklusif sehingga dapat menerapkannya.

\section{UCAPAN TERIMA KASIH}

Pelaksanaan kegiatan pengabdian kepada masyarakat ini tidak lepas dari bantuan, dukungan dan bimbingan dari berbagai pihak, sehingga pada kesempatan ini kami ingin mengucapkan terima kasih kepada Kemenristekdikti yang telah memberikan berupa dana hibah penelitian kepada kami, Ketua STIKES Citra Delima Bangka Belitung, Kader Kelurahan Kacang Pedang, yang telah membantu dalam pelaksanaan kegiatan ini.

\section{DAFTAR PUSTAKA}

Badan Penelitian dan Pengembangan Kesehatan Departemen (2013) Laporan Nasional Riset Kesehatan Dasar (Riskesdas Tahun 2013). jakarta.

Dinas Kesehatan Provinsi Kepulauan Bangka Belitung. (2017) Profil Dinas Kesehatan Provinsi Kepulauan Bangka Belitung. kepulauan bangka belitung.

Ludha, N. and Maulida, I. (2012) 'Hubungan Tingkat Pengetahuan Dan Status Pekerjaan Ibu Menyusui Dengan Pemberian Asi Eksklusif Pada Bayi Di Pesantunan', Jurnal Ilmiah.

Salamah, U. and Prasetya, P. H. (2019) 'FAKTOR-FAKTOR YANG MEMPENGARUHI KEGAGALAN IBU DALAM PEMBERIAN ASI EKSKLUSIF', Jurnal Kebidanan Malahayati. doi: 10.33024/jkm.v5i3.1418.

Savita, R. and Amelia, F. (2020) 'Hubungan Pekerjaan Ibu , Jenis Kelamin , dan Pemberian Asi Eklusif Terhadap Kejadian

\section{SIMPULAN}


329 Penyuluhan ASI Eksklusif Untuk Mencegah Stunting Pada Ibu Hamil Di STIKES Citra Delima Bangka Belitung - Riza Savita, Fitra Amelia

DOI : https://doi.org/10.31004/abdidas.v1i5.64

Stunting Pada Balita 6-59 Bulan di Bangka

Selatan', Jurnal Kesehatan Poltekkes

Kemenkes Ri Pangkalpinang, 8(1), pp. 6-

13.

UNICEF (2013) Data Balita Stunting. indonesia.

Waroh, Y. K. (2019) 'Pemberian Makanan

Tambahan Sebagai Upaya Penanganan

Stunting', Jurnal Kebidanan. 